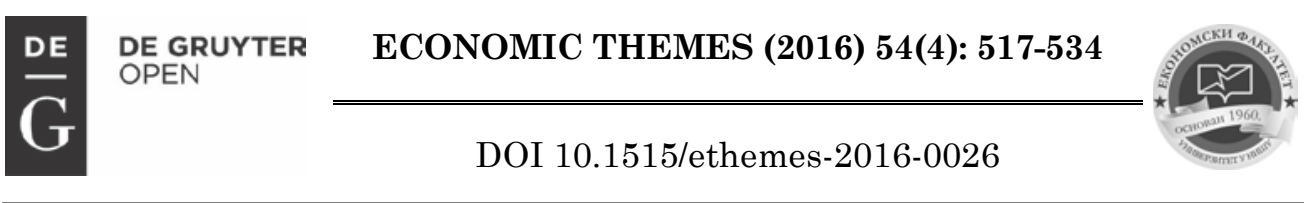

\title{
EFFECTS OF LEAN TOOLS IN ACHIEVING LEAN WAREHOUSING
}

\author{
Aleksandra Anđelković \\ Faculty of Economics, University of Nis, Serbia \\ $\bowtie$ aleksandra.andjelkovic@eknfak.ni.ac.rs \\ Marija Radosavljević \\ Faculty of Economics, University of Nis, Serbia \\ $\bowtie$ marija.radosavljevic@eknfak.ni.ac.rs \\ Danijela Stošić Panić \\ Faculty of Economics, University of Nis, Serbia \\ $\bowtie$ danijela.stosic@eknfak.ni.ac.rs
}

UDC

658.51

Original

scientific

paper

Received: 12.07.2016.

Accepted: 01.02.2017

\begin{abstract}
The acceptance of lean philosophy in the company means not only respecting the lean principles in the manufacturing but in all the processes that are performed inside the company. All processes in the company that are a potential places for making losses and waste and thus require the application of lean principles. Among others, warehouse and warehouse operations, as a centre of costs and waste, must be supported through the implementation of lean philosophy in the company by respecting lean principles. The implementation of lean principles in the warehouse is a certain step of improvement warehouse process and performance, but also of the whole company. In that sense, the paper presents the analysis of the warehousing process and its performances before and after implementation of the lean tools in a selected Serbian company as a practical example. In addition, research shows which parts of warehousing need to be improved, in analysed company, as well as correlation between the individual parts of warehousing, according to employees' opinion from next sectors: purchasing, production and logistics.
\end{abstract}

Keywords: lean manufacturing, lean warehouse, supply chain, performance

JEL classification: C12, L14, M21 


\section{Introduction}

Lean strategy derives from the Japanese manufacturers, especially from the Toyota Motor Corporation, or Toyota Production System (TPS). The emergence of this strategy is the result of resource scarcity and intense competition in the automotive market. Toyota needed an adequate production method for competing with Western automotive companies. TPS's production method success resulted in widespread dispersion of lean philosophy and practice, which started within the Western automotive companies, and then in other industries, companies and countries (Shah \&Ward, 2007). The interest for the lean concept expressed by Western automotive companies was limited until the famous work of Womack, Jones and Roos (1990), The Machine that Changed the World, was published. This book showed the gap in performance between Toyota and other vehicle producers. The goal of lean production is to optimise the performance of the production system according to unique customer requirements (Howell, 1999). Promoting lean business practices has to point out that these strategies are applicable in all companies that have similar, or some general problems in production. This method of production is an alternative to mass production, which is characterised by large batches and hidden losses or hidden waste (Hines et al., 2004, 994). Its purpose is creating a continuous flow with elimination of waste, or muda in Japanese, from the operation of enterprises through a set of synergistic activities to produce goods and services on the market request (Yanget et al., 2011).

The critical point of the lean strategy is focus on value. Often, the creation of value is identified with the costs reduction. In 1996, Womack and Jones emphasised the value as the first principle of the lean strategy. This interpretation of lean production has shifted its focus from reducing the waste and cost to continuous increase of value that is expected by customers. More generally, it emphasises an increase of performances and elimination of certain activities, depending on whether they add value or not. In that way, the customer is the one who decides whether something is muda. Figure 1 shows the relation between value and costs, in terms of lean production. The balance between value and costs provides true value as long as the customer is willing to pay for it. Womack, Jones and Roos (1990) emphasise the value as the first principle of the lean strategy. Changing the focus of lean strategy from reducing waste to creating value for the customer gives opportunity for creating value in the following ways (Hines et al., 2004, 994):

- Value is created by eliminating internal wastes and wasteful activities,

- Value also could be increased with additional benefits, which will be important for the customer, such as a shorter lead time, delivery in small batches, and which will not incur additional costs. 
Figure 1. Relation of costs and value

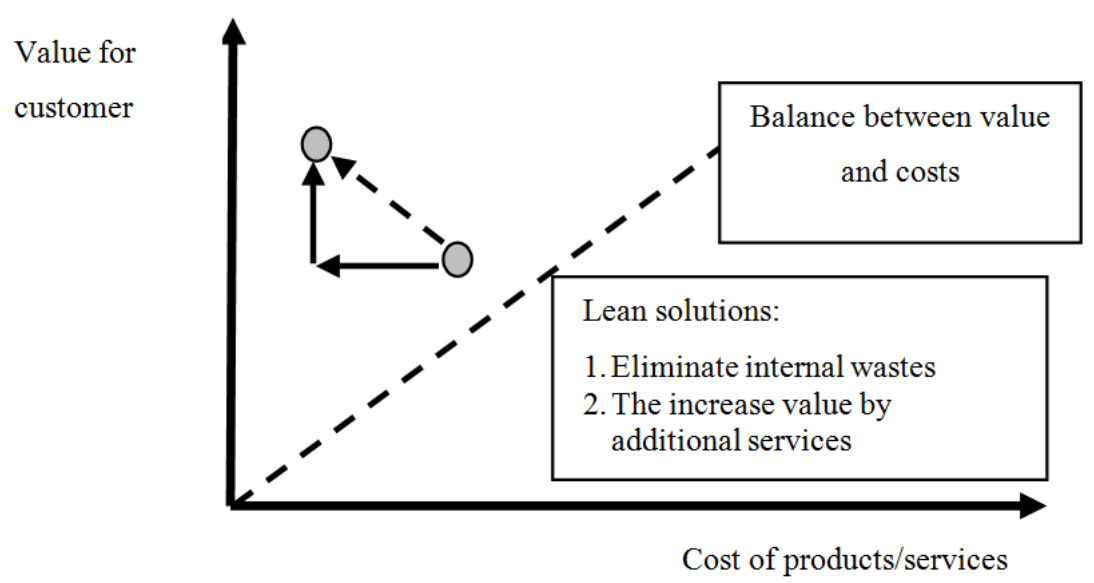

Source: Hines et al., 2004, p. 994.

As an integral part of every logistics system, in order to provide quick response to requests of every partner in the supply chain, warehouse can exist at any point in the supply chain between the suppliers and customers. Even though there is a trend of holding low-level inventory in the warehouse, it is impossible to completely eliminate the warehouse from the supply chain (Richards, 2014, p. 12).Warehouse and inventory management are supporting production and insist on full coordination between all functions, such as marketing, finance, human resources and others. Any disruption in the coordination can cause serious problems throughout the business process. In the same time the share of the warehouse costs in the total logistics cost is not negligible. According to certain findings, in the United States warehouse costs (operating and capital) are participating with 23 percent in the total logistics costs (Baker \& Canessa, 2009, p. 426), while in Europe these costs have reached 39 percent of the total logistics costs (Fumi et al., 2013). Also, costs of warehousing participate in the total costs of a company from 2 to 5percent (Camacho, 2011), and these costs consists of labour costs (60 percent), space (25 percent) and equipment (15 percent) (Argusi, 2016; Emmett, 2005, p. 175).

Beside the fact that the warehouse represents a key loop in a logistics system, in terms of value-added activities and providing higher level of service, one should also bear in mind the costs incurred in carrying out operations in the warehouse. Therefore, there is a clear need for the elimination of losses in this part of the logistics system. In other words, lean orientated companies need to be lean in all of their parts. Due to this fact, the goal of the companies should be implementation of actions for creating lean warehousing, which includes the elimination of all operations that do not add value to the product or increase the level of service. 
Positive effects from implementing of lean tools are undisputed, as it can be seen on Toyota's example. However, the question is: Are companies from the Republic of Serbia able to implement the same or similar tools? Do companies from the Republic of Serbia recognise the importance and positive effects from implementation of lean tools? Do companies implement lean tools with purpose of improving different business processes? Results of the research, partly presented in this paper has aim to answer these research questions. In that regard, the following subheadings will describe the concept of lean warehousing and its main characteristics, and indicate the importance and effects of the lean warehousing, illustrated by a case of the automotive industry.

\section{Lean Warehousing Concept}

The essence of the lean philosophy is reflected in the elimination of waste and losses, but also in striving for constant improvement. Katayama and Bennett (1999, p. 44) state that when a company makes a decision to adopt the lean philosophy; the main objective becomes the implementation of the strategy of reducing costs and increasing the market share. Liker (2004) emphasises that the essence of the Toyota's success is in fostering leadership, teamwork, building relationships with suppliers and encouraging organisations to learn. According to Liker, Toyota, which is an example of lean business, is constantly striving for perfection - nothing is so good that cannot be improved. Therefore, one of the main focuses is the process of continuous improvement. Ohno (1988) states that the main goal of the lean production is reduction of losses or waste. He points out that changes in the quality and operations management practices are used in order to improve the production process.

The term lean manufacturing is mentioned first time in the benchmarking study of global quality cars and productivity conducted by the International Motor Vehicle Program, at the Massachusetts Institute of Technology, in 1979. Womack, Jones and Ross (1990) are responsible for transferring the TPS to the Western world. According to these authors, the benefits of lean manufacturing are savings of the half of the human effort in the factory, half of the manufacturing space, half of the investment in tools, half of the time to develop a new product, half of the inventory, which leads to a reduction in defects and losses (Toledo \& Vagner, 2009). For example, five years of researching performance of the global auto industry conducted by the International Motor Vehicle Program, showed that the productivity of Japanese manufacturers was higher than that of the manufacturers from Europe and USA. As the International Motor Vehicle Program finds, the main reason for that performance gap is the implementation of the lean strategy which resulted in shorter lead time, reduction in the raw material costs and improved quality (Lewis, 2000).The need to improve and maintain competitive advantage puts the lean philosophy in first plan. However, it is wrong to believe that the lean 
business and competitive advantage of the company can be possible only by achieving lean production. All processes in the company must be organised with respect of the principles of lean strategy, and by eliminating activities that do not add value. In that sense, process of warehousing is one of the many processes in company that is very important in the process of achieving lean business.

According to Dehdari (2013), lean warehousing is a concept that requires constant, systematic, sustainable and measurable improvement of warehousing process with a full participation of all employees. Additionally, warehouse is responsible for adding value to the customer by creating utility of the time and place, but also this is a logistics area that can cause many types of waste. Lean warehousing can also be defined as a reduction of waste concept in upstream or downstream supply chain, depending on the location and function of the warehouses in the supply chain, in order to address the right customer, at the right time and place (Reichart \& Holweg, 2007). Researches and studies were conducted with a purpose to determine the impact of lean warehousing on performance. For example, one of the studies shows that the British auto industry has increased inventory turnover to 177.4 percent in the period from 1992 to 1994 (Oliver et al., 1996). It seems like the lean warehousing is becoming an attractive research field. Nevertheless, studies on lean warehousing are not abundant. Table 1 shows the results of certain studies which indicate that, beside production, warehousing can be a perfect area for implementing lean strategy and achieving expected results.

Table 1. Effects of implementing lean philosophy in the warehouse system

\begin{tabular}{|c|c|c|}
\hline Study & Area & Effect \\
\hline Cook et al. (2005) & Warehousing & $\begin{array}{l}71 \% \text { decrease in inbound cycle time, } 76 \% \text { decrease in } \\
\text { inventory levels, required storage space decreased by } 51 \%\end{array}$ \\
\hline Dehdari (2013) & Warehousing & increase warehouse productivity by at least $5 \%$ \\
\hline $\begin{array}{l}\text { Demeter and } \\
\text { Matyusz (2011) }\end{array}$ & Manufacturing & $\begin{array}{l}35,8 \% \text { reduction of inventory days of raw materials, } 33,8 \% \\
\text { reduction of inventory days of work in progress, } 46,9 \% \\
\text { reduction of inventory days of finished goods }\end{array}$ \\
\hline Jaca et al. (2012) & Warehousing & $9,34 \%$ improvement in overall warehouse productivity \\
\hline $\begin{array}{l}\text { Shah and Ward } \\
\text { (2003) }\end{array}$ & Manufacturing & $\begin{array}{l}\text { Positive influence on scrap costs, cycle time, lead-time, } \\
\text { labour productivity and manufacturing costs }\end{array}$ \\
\hline Swank (2003) & $\begin{array}{l}\text { Warehousing } \\
\text { and services }\end{array}$ & $\begin{array}{l}60 \% \text { reduction in response time, } 28 \% \text { reduction in labour } \\
\text { costs and, } 40 \% \text { reduction of reissues due to errors. }\end{array}$ \\
\hline
\end{tabular}

Source: Visser, J. J. (2014) Lean in the warehouse: Measuring lean maturity and performance within a warehouse environment. Rotterdam School of Management, Erasmus University Rotterdam.

Due to the fact that warehouse and warehouse operations are not only a source of costs, but also source of competitive advantage through higher level of service, acceptance of the lean culture in the warehouse will contribute to greater value and lower costs. Mahfouz emphasises that the aim of the lean warehousing is 
increasing responsiveness to market requests and reducing the total costs by simplifying distribution operations (Visser, 2014, p. 21). It is the fact that responsiveness is a part of the agile strategy more than of the lean strategy. However, in the modern business conditions it is difficult to separate the lean from the agile strategy. The reason for that is the fact that lean and agile strategies are both focused on reduction of lead time and satisfaction of market demands (Barac \& Anđelković, 2016).

Lean warehousing is focused on adequate and efficient order request. It involves minimising non-value adding activities at all warehouse operations: receiving, storing, picking order, packing and shipping (Myerson, 2012). So, if a company wants to achieve lean warehousing it is necessary to minimise non-value adding activities, and accordingly to identify sources of waste. Similar to the production, seven types of waste can be recognized in the warehouse (Haan et al., 2009; Four Principles: The Lean Management Experts):

- Defects - involves activities caused by rework, returns of adjustment according to customer request because handling and shipment of defective, damaged, wrong or mislabelled products, mistakes, inventory discrepancies or materials missing,

- Overproduction - replenishing, packing and picking products before they are needed,

- Waiting - includes waiting for inspection and control, picking, shipping, waiting for data,

- Unnecessary movement - involve unnecessary movement of employees caused by inefficient routing,

- Unnecessary inventory -every situation that causing excess of inventory and freezing companies' assets or stock out and non-optimal use of space,

- Transporting - involve unnecessary internal transport of inventory (materials or products) and

- Inappropriate processing -include activities of unnecessary inspection, picking and packing orders.

By looking at the list of wastes that may occur in the warehouse, it can be concluded that the warehouse, besides the production, is an ideal area for the implementation of the lean strategy. The application of lean strategy in warehouse will focus on eliminating losses, and therefore on minimising the warehouse costs. As a result, one can expect increasing competitive advantage on the basis of efficient and effective response to the requests from customers.

\section{Implementation of Lean Tools in the Warehouse}

Global logistics strategy based on focused factories, postponement and aggregation of inventory, shows that warehouse and warehousing operations are becoming one 
of the most important areas for achieving competitive advantage, not just for the companies but for the whole supply chain. In that sense, in integrated global economy market, warehouse is becoming very important link for facing with demand variations, both upstream and downstream in the supply chain. Besides that, warehouse is becoming a key part of a supply chain, with so much potential for improving service level and minimising cost (Four Principles: The Lean Management Experts). Those who recognised this warehouse's potential have a lot of possibilities to be example of the best practice.

Figure 2. Potential Savings in Warehouse by Lean Steps

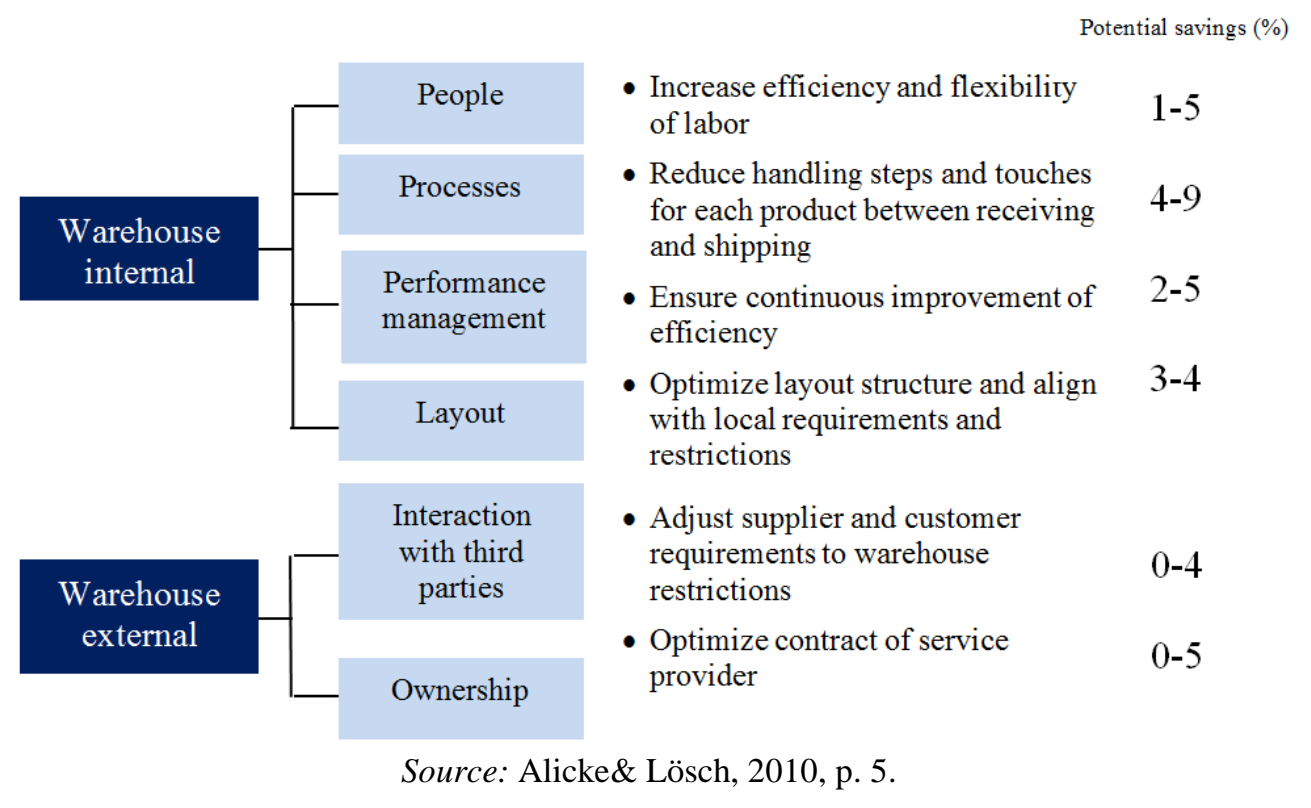

There are certain rules that have to be followed in order to ensure the efficiency of operations in the warehouse. The flow of raw materials/finished products must be continuous with the avoidance of double handling, which increases the cost of materials handling. In order to achieve transparency of the material within the warehouse it is recommended that it has to be tracked by scanning it during each of the material's handling activity (Bartholdi \& Hackman, 2008, p. 21). For the purpose of eliminating sources of waste, inflexibility and inefficiency in the warehouse, it is necessary to implement some lean tools. Most of them require little or no financial resources and are used for the improvement of the following segments: processes, people, performance management, interaction with third parties, and having the appearance of the warehouse. Next figure shows potential savings with implementation of some steps in mentioned areas.

What is Toyota for lean manufacturing that is Menlo Worldwide Logistics for lean warehousing. Menlo Worldwide Logistics is the company that has become 
well known by implementation of lean concept at warehouse. As it is mentioned, lean strategy is well known as a production strategy, but the last few decades, many companies were trying to implement principles of lean strategy in their manufacturing.

Table 2. Results of implementing lean principles in the Menlo Worldwide Logistics warehouse

\begin{tabular}{|l|r|}
\hline \multicolumn{1}{|c|}{ Area } & \multicolumn{1}{c|}{ Impact (over 3 years) } \\
\hline Improvement of productivity (per year) & $4.96 \%$ to $8.13 \%$ \\
\hline Reduction of picking error & $.004 \%$ to $.09 \%$ \\
\hline Inventory accuracy & $.0046 \%$ to $.0078 \%$ \\
\hline Safety: lost-time accidents reduced & $2.5 \%$ to $5.56 \%$ \\
\hline Saved warehouse space & $8.55 \%$ to $14.65 \%$ \\
\hline
\end{tabular}

Source: Bartholomew, D. (2008) Putting Lean Principles in the Warehouse, Lean Enterprises Institute, http://www.lean.org/common/display/?0=813 (Accessed 23 April 2016)

However, at the same time Menlo Worldwide Logistics implemented lean principles in the warehouse and in distribution centre. In that sense, ten years ago, this company started with transformation of its 16 million square feet warehouse space according to the lean principles. The main reasons for this can be summarised as: speed the material flow, drive out waste, and reduce inventory. After first five months of implementation of the lean principles, Menlo Worldwide Logistics achieved the following results: higher level of inventory accuracy (from 60 to $99 \%$ ), lower value of inventories (26\%); reduced stock out for $90 \%$, and elimination of $95 \%$ of expedited freight costs (Bartholomew, 2008).

\section{Results of the Lean Tools Implementation in the Automotive Industry in the Republic of Serbia}

Implementation of the lean strategy by Serbian companies is relatively unexplored area (Todorović, 2013). One of the few studies show that Serbian large companies do not have a hollistic approach to the lean business practice (Stošić et al., 2016). Namely, the waste reduction practices and delegating the responsibilities as elements of the lean production strategy are not sufficiently implemented by Serbian companies. Beside lean production, lean warehousing is rarely a subject of empirical research of the Serbian business environment. Therefore, with an aim to test the compatibility of the Serbian business practices with the results of other studies, the effects of implementation of the lean tools in the warehouse of a company from the Serbian automotive industry has been analysed. Respecting the 
anonymity of the company, its name will not be mentioned. Company from the automotive industry was selected due to the fact that the lean strategy was implemented in the automotive industry for first time. In addition, in order to measure the effects of application of the lean tools in the warehouse, it has been necessary to choose a company that implements such tools, as was the case with the analysed company. Manufacturing in the analysed company was based on the lean principles even before lean tools were implemented in the warehouse. However, implementing the lean tools within the manufacturing was not successful in terms of elimination of the waste within the warehouse and expected increase of productivity.

The company has recognised that the process and time of transferring materials in production are some of the key wastes. Based on the frequency of transferring materials into the production, company defined high runner materials (this material is needed in each shift) and low runner materials (needs for this material are on 1-3 days). For the high runner materials an additional space in the warehouse, near to the production process, was determined. This action has led to the significant improvements and elimination of losses, as shown in the following table.

Table 3. Results of implementing lean principles in the company's warehouse

\begin{tabular}{|l|c|c|}
\hline \multicolumn{1}{|c|}{ Area } & Before improvement & After improvement \\
\hline $\begin{array}{l}\text { Reduction of picking error -before } \\
\text { and now }\end{array}$ & $0.17 \%$ & $0.01 \%$ \\
\hline $\begin{array}{l}\text { Inventory accuracy - difference on } \\
\text { stock take (physical count versus } \\
\text { system stock) }\end{array}$ & $9.29 \%$ & $5.97 \%$ \\
\hline $\begin{array}{l}\text { Safety: lost-time accidents reduced } \\
\text { (depend from group of material) }\end{array}$ & $15-20$ days & $7-10$ days \\
\hline Saved warehouse space & $\begin{array}{c}2400 \mathrm{~m}^{2} \text { planned for } 2 \\
\text { projects before }\end{array}$ & $\begin{array}{c}2400 \mathrm{~m}^{2} \text { used for all } \\
\text { projects (4 projects) }\end{array}$ \\
\hline
\end{tabular}

Source: Company’s internal documentation

Despite of the achieved results, employees and managers of logistics, purchase and production at the company considered that the warehouse and warehouse operations still have to be improved. The employees' opinion from these areas is recognised as important because the logistics, purchasing and production are directly connected with the warehouse. Accordingly, it is expected that those employees can best assess what need to be improved in the following period, in order to implement the lean principles in the warehouse. Moreover, employees as well as managers from these sectors are focused on the priorities and directions for further improvement, in terms of eliminating the waste from warehouse. The sample of 39 employees was defined with the following structure: 18 employees 
from the logistics sector, 10 from the procurement sector and 11 from the production sector.

Descriptive statistics in Table 4 shows how employees (selected randomly) had ranked some segments of warehouse that need to be improved, using scores from 1 to 8 ( 1 mean the highest priority for improving). As the results show, there is a certain divergence in the priority perceptions of employees from different sectors. Employees from the logistics assess that the Order-picking is priority for further improvement (average score 1.44). Further, minimal standard deviation regarding this warehouse activity (0.51) suggests that there is the greatest agreement among the employees that this area needs further improvement. In order to increase the leanness of the warehouse, employees from the purchase sector highlight that internal transport must be improved (1.60), while the highest level of agreement among the employees from this sector is present for the areas of Inventory management, Order-picking and Information technology (0.79). Finally, the employees from the production sector believe that further improvements need to be focused on Schedule inventory in the warehouse and, at the same time; there is the greatest agreement among the production employees that Schedule inventory is the best candidate for further improvements. However, based on the aggregate rankings of all of the variables for the entire sample, Inventory management is the area that has the greatest mean score (2.62) and is marked as a priority for further improvements. The results of the descriptive statistics suggest that employees expect that the Inventory management will generate significant wastes and that is why it must be a priority for future improvements.

As the descriptive statistics showed that there are certain differences among the employees from different sectors regarding the priority warehouse activities that have to be improved, the statistical importance of these differences has been tested by conducting an analysis of variances. In that sense, following hypotheses were defined:

$\mathrm{H}_{0}$ : There are no differences in the attitudes of employees from different sectors concerning the elements of warehouse that should be improved;

$\mathrm{H}_{1}$ : There are differences in the attitudes of employees from different sectors concerning the elements of warehouse that should be improved. 
Table 4. Descriptive statistics

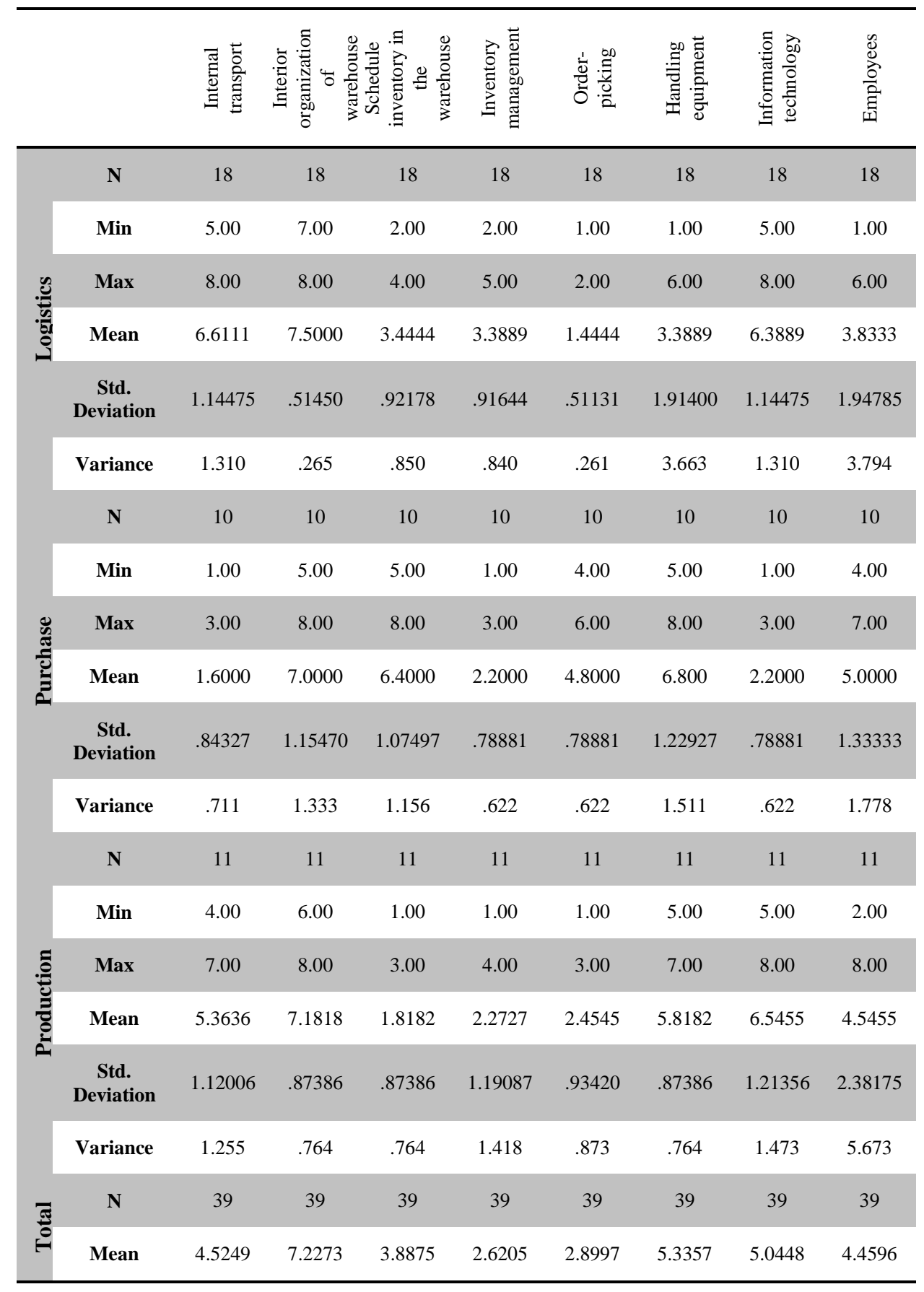

Source: Authors' calculation based on survey data 
Table 5. ANOVA

\begin{tabular}{|c|c|c|c|c|c|c|}
\hline & & Sum of Squares & df & Mean Square & $\mathbf{F}$ & Sig. \\
\hline \multirow{3}{*}{ Internal transport } & Between Groups & 163.751 & 2 & 81.876 & 71.501 & .000 \\
\hline & Within Groups & 41.223 & 36 & 1.145 & & \\
\hline & Total & 204.974 & 38 & & & \\
\hline \multirow{3}{*}{$\begin{array}{l}\text { Interior } \\
\text { organization of } \\
\text { warehouse }\end{array}$} & Between Groups & 1.761 & 2 & .881 & 1.313 & .281 \\
\hline & Within Groups & 24.136 & 36 & .670 & & \\
\hline & Total & 25.897 & 38 & & & \\
\hline \multirow{3}{*}{$\begin{array}{l}\text { Schedule inventory } \\
\text { in the warehouse }\end{array}$} & Between Groups & 112.955 & 2 & 56.478 & 62.597 & .000 \\
\hline & Within Groups & 32.481 & 36 & .902 & & \\
\hline & Total & 145.436 & 38 & & & \\
\hline \multirow{3}{*}{$\begin{array}{c}\text { Inventory } \\
\text { management }\end{array}$} & Between Groups & 12.863 & 2 & 6.432 & 6.798 & .003 \\
\hline & Within Groups & 34.060 & 36 & .946 & & \\
\hline & Total & 46.923 & 38 & & & \\
\hline \multirow{3}{*}{ Order-picking } & Between Groups & 72.664 & 2 & 36.332 & 69.677 & .000 \\
\hline & Within Groups & 18.772 & 36 & .521 & & \\
\hline & Total & 91.436 & 38 & & & \\
\hline \multirow{3}{*}{$\begin{array}{l}\text { Handling } \\
\text { equipment }\end{array}$} & Between Groups & 86.383 & 2 & 43.192 & 18.618 & .000 \\
\hline & Within Groups & 83.514 & 36 & 2.320 & & \\
\hline & Total & 169.897 & 38 & & & \\
\hline \multirow{3}{*}{$\begin{array}{l}\text { Information } \\
\text { technology }\end{array}$} & Between Groups & 134.369 & 2 & 67.185 & 56.769 & .000 \\
\hline & Within Groups & 42.605 & 36 & 1.183 & & \\
\hline & Total & 176.974 & 38 & & & \\
\hline \multirow{3}{*}{ Employees } & Between Groups & 9.439 & 2 & 4.720 & 1.238 & .302 \\
\hline & Within Groups & 137.227 & 36 & 3.812 & & \\
\hline & Total & 146.667 & 38 & & & \\
\hline
\end{tabular}

Source: Authors' calculation based on survey data

ANOVA results show that null hypotheses should be rejected in all cases and for all variables, except for the variables: Internal organisation of the warehouse and employees (Sig.> 0.05). In other words, in the most cases employees from different functional sectors in the company have different perceptions about the warehouse activities that should be improved in order to minimize waste. These differences and disagreements among the sectors that are complementary and directly related with the warehouse can cause serious problems for the company in the future. 
Table 6. Correlations between variables (Spearman's rho)

\begin{tabular}{|c|c|c|c|c|c|c|c|c|c|}
\hline & & 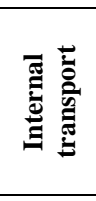 & 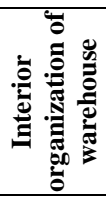 & 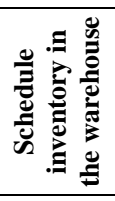 & 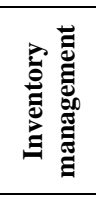 & 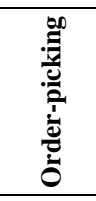 & 此泀 & 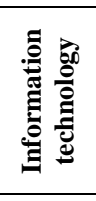 & 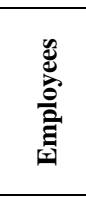 \\
\hline \multirow{2}{*}{ 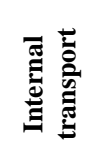 } & $\begin{array}{l}\text { Correlation } \\
\text { Coefficient }\end{array}$ & 1.000 & .235 & $-.602^{* *}$ & $.400^{*}$ & $-.815^{* *}$ & $-.737^{* *}$ & $.372^{*}$ & -.018 \\
\hline & $\begin{array}{l}\text { Sig. (2- } \\
\text { tailed) }\end{array}$ & & .149 & .000 & .012 & .000 & .000 & .020 & .914 \\
\hline \multirow{2}{*}{ 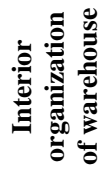 } & $\begin{array}{l}\text { Correlation } \\
\text { Coefficient }\end{array}$ & .235 & 1.000 & .160 & $.393^{*}$ & -.266 & $-.629^{* *}$ & .085 & -.286 \\
\hline & $\begin{array}{l}\text { Sig. (2- } \\
\text { tailed) }\end{array}$ & .149 & & .330 & .013 & .102 & .000 & .606 & .078 \\
\hline \multirow{2}{*}{ 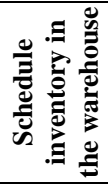 } & $\begin{array}{l}\text { Correlation } \\
\text { Coefficient }\end{array}$ & $-.602^{* *}$ & .160 & 1.000 & .094 & $.438^{* *}$ & .167 & $-.489^{* *}$ & -.094 \\
\hline & $\begin{array}{l}\text { Sig. (2- } \\
\text { tailed) }\end{array}$ & .000 & .330 & & .568 & .005 & .310 & .002 & .568 \\
\hline \multirow{2}{*}{ 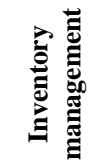 } & $\begin{array}{l}\text { Correlation } \\
\text { Coefficient }\end{array}$ & $.400^{*}$ & $.393^{*}$ & .094 & 1.000 & $-.705^{* *}$ & $-.619^{* *}$ & $.357^{*}$ & $-.355^{*}$ \\
\hline & $\begin{array}{l}\text { Sig. (2- } \\
\text { tailed) }\end{array}$ & .012 & .013 & .568 & & .000 & .000 & .026 & .027 \\
\hline \multirow{2}{*}{ 茴 } & $\begin{array}{l}\text { Correlation } \\
\text { Coefficient }\end{array}$ & $-.815^{* *}$ & -.266 & $.438^{* *}$ & $-.705^{* *}$ & 1.000 & $.713^{* *}$ & $-.532^{* *}$ & .266 \\
\hline & $\begin{array}{l}\text { Sig. (2- } \\
\text { tailed) }\end{array}$ & .000 & .102 & .005 & .000 & & .000 & .000 & .102 \\
\hline \multirow{2}{*}{ 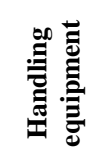 } & $\begin{array}{l}\text { Correlation } \\
\text { Coefficient }\end{array}$ & $-.737^{* *}$ & $-.629^{* *}$ & .167 & $-.619^{* *}$ & $.713^{* *}$ & 1.000 & -.229 & -.007 \\
\hline & $\begin{array}{l}\text { Sig. (2- } \\
\text { tailed) }\end{array}$ & .000 & .000 & .310 & .000 & .000 & & .160 & .967 \\
\hline \multirow{2}{*}{ 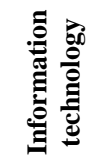 } & $\begin{array}{l}\text { Correlation } \\
\text { Coefficient }\end{array}$ & $.372^{*}$ & .085 & $-.489^{* *}$ & $.357^{*}$ & $-.532^{* *}$ & -.229 & 1.000 & $-.688^{* *}$ \\
\hline & $\begin{array}{l}\text { Sig. (2- } \\
\text { tailed) }\end{array}$ & .020 & .606 & .002 & .026 & .000 & .160 & & .000 \\
\hline \multirow{2}{*}{ 冚 } & $\begin{array}{l}\text { Correlation } \\
\text { Coefficient }\end{array}$ & -.018 & -.286 & -.094 & $-.355^{*}$ & .266 & -.007 & $-.688^{* *}$ & 1.000 \\
\hline & $\begin{array}{l}\text { Sig. (2- } \\
\text { tailed) }\end{array}$ & .914 & .078 & .568 & .027 & .102 & .967 & .000 & \\
\hline
\end{tabular}

** Correlation is significant at the 0.01 level (2-tailed).

* Correlation is significant at the 0.05 level (2-tailed).

Source: Authors' calculation based on survey data 
At the sample level (all the employees), descriptive statistics results showed that the Inventory management is a part of the warehouse which is considered to be a priority for further improvements in order to eliminate wastes. By determining the level of correlation between various warehouse activities it may be possible to determine those warehouse activities that will be indirectly improved by improving the Inventory management. In order to do so, a correlation between the analyzed variables was assessed by using the Spearman's correlation (Table 6).

As the result show, the highest correlation was identified between the Orderpicking and the activity of Handling the equipment (0.713), with high level of significance (0.000), In addition, correlation with high level of significance was found between the Inventory management and the Internal transport $(0.400)$, between the Information technology and the Inventory management (0.357), the Internal transport and the Information technology (0.372), the Order-picking and the Schedule inventory in the warehouse (0.438), and between the Internal organisation of the warehouse and the Inventory management (0393), With respect to the correlation results, it can be concluded that the implementation of the lean tools in order to improve the Inventory management can indirectly improve the Internal transport, the Information technology and the Internal organisation of the warehouse.

\section{Conclusion}

Warehouse managers have an important task to increase the productivity and accuracy, reduce cost and inventory, and, at the same time, to provide higher level of service (Four Principles: The Lean Management Experts, Lean Warehousing Operations). However, there is no predetermined formula or recipe for performing that task. One of the ways that warehouse managers may use is the application of the lean tools. The importance of lean warehousing might be noticed from the statement of the Former chief operating officer of Menlo Worldwide Logistics, Gary Kowalski, who said: "The leaner you are, the more integrated view you have of transportation and warehousing” (Bartholomew, 2008).

According to analysed studies of the effects and results before and after the implementation of lean tools, substantial improvements in warehouse performances can be seen. This is also confirmed on the example of the company that has been the subject of the analysis, partly presented in this paper. Descriptive statistics has shown that employees give priority to Inventory management, in terms of improvement. Therefore, despite of the results achieved as a consequence of the improved schedule inventory in the warehouse, employees believe that there are possibilities for further improvement of this part of the warehousing. According to the majority of the employees, Inventory management has been recognised as a place that can significantly contribute to the savings in terms of time and costs. 
Analysis of variance showed that between employees from different sectors of the company there are significant differences in the perception of the warehouse activities that can be marked as priorities for further improvements. These differences can present a barrier for the process of implementation of lean tools in the future. Namely, these disagreements can cause various conflicts between sectors, and thus slow down or prevent future improvements. Moreover, the analysis of correlation between different warehouse activities showed that out of six cases, where significant and high correlations were found, Inventory management was one of the correlated variables in three cases. Therefore, it can be concluded that, beside the fact that employees recognise Inventory management as a part of warehousing that should be improved in order to achieve lean performances, this warehouse activity has significant influence on others areas of warehousing. However, this is a pilot study, which can serve as a basis for more detailed analysis with a significantly larger sample, including companies of different size, from different industries, with a greater share of the domestic or foreign capital, and etc. With that kind of an analysis, it will be possible to identify in which companies and industries it is justifably to implement lean strategies. Especially, because previous studies have shown that this strategy gave noticeable results in just a few industries (automotive industry and airline industry) (Lowe et al., 1997; Shah \&Ward, 2003). Finally, it may be said that lean, as a strategy is not new, but lean warehousing is relatively new concept. When one speaks about the lean strategy the focus is still on manufacturing. The notion that other parts of a business can be suitable for the lean practices is supported by the results presented in the paper which suggest that there can be considerable and positive influence of lean tools implementation in the warehouse. Therefore, it is necessary to promote implementation of lean tools in order to achieve lean warehousing and, consequently, to achieve better results in the company, as a whole.

\section{References}

Alicke, K. \& Lösch, M. (2010). Lean and mean: How does your supply chain shape up? McKinsey \& Company.

Argusi, European Warehousing Labor Cost. http://www.argusi.org/en/europeanwarehousing-labor-cost/(Accessed 20 March 2016).

Baker, P. \& Canessa, M. (2009). Warehouse design: a structured approach. European Journal of Operational Research. 193, 425-436.

Barac, N. \& Anđelković, A. (2016). Od lean i agilne do hibridne strategije lanca snabdevanja. Tematski zbornik: Antikrizne politike i postkrizni procesi: Izazovi ekonomske nauke. Urednik Marija Radosavljević. Ekonomski fakultet. Univerzitet u Nišu, 333-346.

Bartholomew, D. (2008).Putting Lean Principles in the Warehouse. Lean Enterprises Institute. Retrieved from: http://www.lean.org/common/display/?o=813, Accessed on April 23, 2016. 
Camacho, M. V. (2011).Warehouse Logistics and Internal Distribution Optimization. Instituto Superior Tecnico. Universidade Tecnica de Lisboa.

Dehdari, P. (2013).Measuring the Impact of Lean Techniques on Performance Indicators in Logistics Operations. Doctoral dissertation. Faculty of Mechanical Engineering. Institute of Technology. Karlsruhe. Germany.

Demeter, K. \& Matyusz, Z. (2011). The Impact of Lean Practices on Inventory Turnover. International Journal of Production Economics, 133(1), 154-163.

Emmett, S. (2005).Excellence in Warehouse Management: How to Minimise Costs and Maximise Value. Chichester: John Wiley \& Sons Ltd.

Four Principles: The Lean Management Experts. Lean Warehousing Operations. http://www.fourprinciples.ae/solutions/lean-warehouse-operations\#.V4IxT-t97IW (Accessed 20 May 2016).

Fumi, A. Scarabotti, L. \& Schiraldi, M. M. (2013). The Effect of Slot-Code Optimization in Warehouse Order Picking. International Journal of Engineering Business Management, 5(20), 1-10.

Haan, de J. Overboom, M. \& Naus. F. (2011).Lean Logistics Service Providers: Option or Utopia? Experiences from the Netherlands. Changing Paradigm for Inventory Management in a Supply Chain Context (ed. D. Kisperska-Moron), pp. 78-97.

Hines, P., Holweg, M. \& Rich, N. (2004). Learning to Evolve: A Review of Contemporary Lean Thinking. International Journal of Operations \& Production Management, 24 (10), 994-1011.

Howell, G. A. (1999). What is Lean Construction? Proceedings of the 7th Conference of the International Group for Lean Construction. Berkeley. California. USA, 26-28 July 1999.

Katayama, H. \& Bennett, D. (1999). Agility. adaptability and leanness: a comparison of concepts and a study of practice. International Journal of Production Economics, 60, 43-51

Lewis, M. A. (2000). Lean production and sustainable competitive advantage. International Journal of Operations \& Production Management, 20(8), 959 - 978.

Liker, J. (2004). The Toyota Way: 14 Management Principles from the World's Greatest Manufacturer. New York: McGraw Hill.

Lowe, J., Delbridge, R. \& Oliver, N. (1997). High-Performance Manufacturing: Evidence from the Automotive Components Industry. Organization Studies, 18 (5), 783-798.

Myerson, P. (2012). Lean supply chain and logistics management. McGraw-Hill.

Ohno, T. (1988). Toyota Production System - Beyond Large Scale Production. New York: Productivity Press.

Oliver, N., Delbridge. R, \& Lowe. J. (1996). Lean Production Practices: International Comparisons in the Auto Components Industry. British Journal of Management 7. Special Issue, S29-S44.

Reichart, A. \& Holweg, M. (2007). Lean Distribution: Concepts. Contributions and Conflicts. International Journal of Production Research, 45(16), 3699-3722.

Richards, G. (2014).Warehouse Management. London. KoganPage.

Shah, R. \& Ward, P. T. (2003). Lean Manufacturing: Context. Practice Bundles. and Performance. Journal of Operations Management, 21 (2), 129-149.

Shah, R. \& Ward, P. T. (2007). Defining and developing measures of lean production. Journal of Operations Management, 25, 785-805. 
Stošić, D., Anđelković, A. \& Radosavljević, M. (2016). The Contribution of the Lean Production Strategy to the Value Creation Process and Competitiveness of the Large Companies in the Republic of Serbia. Proceedings from the XXI Internacionalni naučni skup SM 2016 Strategijski menadžment i sistemi podrške odlučivanju u strategijskom menadžmentu, (pp. 1296-1304), Palić, 19 May 2016. University of Novi Sad - Faculty of Economics Subotica.

Todorović, M. (2013). Obračun troškova po aktivnostima baziran na vremenu - instrument integrisanog upravljanja lean poslovnim procesima. Doctoral dissertation. University of Kragujevac - Faculty of Economics.

Toledo. , G. K. \& Vagner, C. (2009).Measuring performance and Lean Production: a review of literature and a proposal for a Performance Measurement System. POMS 20th Annual Conference Orlando. Florida U.S.A. May 1 to 4. 2009.

Visser, J. J. (2014). Lean in the warehouse: Measuring lean maturity and performance within a warehouse environment. Rotterdam School of Management. Erasmus University Rotterdam.

Womack, J. \& Jones, D. (1996). Lean Thinking. Simon \& Schuster. New York: USA.

Womack, J., Jones, D. \& Roos, D. (1990). The Machine that Changed the World. Macmilan Publishing Company. New York: USA.

Yang, M. M., Hong, P. \& Modi, B. S. (2011). Impact of Lean Manufacturing and Environmental Management on Business Performance: An Empirical Study of Manufacturing Firms. International Journal Production Economics, 129, 251.

\section{EFEKTI LEAN ALATA U POSTIZANJU LEAN SKLADIŠTENJA}

Apstrakt: Primena lean filozofije u kompaniji ne znači samo poštovanje lean principa na nivou proizvodnje, već na nivou svih procesa koji postoje unutar kompanije. Svi procesi unutar kompanije koji su potencijalni izazivači gubitaka i otpadaka zahtevaju primenu lean principa. Pored ostalih, skladište i skladišne operacije, kao centar troškova i gubitaka, mora biti podrška u implementaciji lean filozofije u kompaniji, uz poštovanje lean principa. Implementacija lean principa $u$ skladištu je siguran korak u poboljšanju skladišnih procesa i performansi skladišta, ali i čitave kompanije. U tom smislu. autori rada ce ukazati na proces skladištenja i njegove performanse pre i nakon primene lean alata u odabranoj kompaniji, kao praktičnom primeru. Osim toga, istraživanje pokazuje koje delove skladištenja treba unaprediti, u analiziranoj Kompaniji, kao i korelaciju između pojedinih delova skladištenja, prema mišljenju zaposlenih iz sledećih sektora: nabavka, proizvodnja i logistika.

Ključne reči: lean proizvodnja, lean skladište, lanac snabdevanja, performanse

\section{Authors' biographies}

Aleksandra Anđelković is an Assistant Professor at the Faculty of Economics, University of Nis, for narrow scientific field of Business 
management, for the group of courses Strategic Logistics Management, International Logistics, Marketing Channels, and International Marketing. In 2015, she defended the doctoral dissertation with the title Supply chain risk management for the purpose of increasing its resilience. Until now she was two times a scholar and researcher of Austrian Agency for International Cooperation in Education and Research, at the University of Vienna (2013), and Vienna University of Economics and Business (2016). Her key interest areas are: strategic management of logistics, international logistics, supply chains, international marketing, and marketing channels. So far, she has published more than 40 papers in journals and proceedings from the conferences (national and international).

Marija Radosavljević is an Associate Professor at the Faculty of Economics, University of Nis, for narrow scientific field business management. In 2001,she graduated from the Faculty of Economic in Nis, as a student of generation and defended Master's and doctoral thesis at the Faculty of Economics in Belgrade in 2004 and 2009, respectively. She has participated in few projects, financed by the Ministry of Science of Republic of Serbia. In 2005, 2009 and 2011 she was engaged as a researcher at the University for Economics and Business Administration, Department for Production Management, Wien, Austria and in 2013 as a visiting professor at Willamette University, Atkinson Graduate School of Management, Oregon, USA, as the only candidate from Serbia. Her key interest areas are: quality management, process management, cost management, human resource management. So far, she has published more than 130 papers in journals and proceedings from the conferences (national and international) and 5 monographs.

Danijela Stošić Panić, PhD, is Assistant Professor at the Faculty of Economics, University of Niš, for the narrow scientific field: business management (teaching courses: Business Planning and Policy, Strategic Management, Production Management). She has published over 30 papers in the peer reviewed journals and other scientific publications. She has been an active participant of various domestic and international scientific projects and scholarship holder of various domestic and international organizations. Moreover, she has been an associate of the Commission of the Accreditation and Quality Insurance for the higher education institutions in the Republic of Serbia. 